\title{
Characterization of Kinnow Mandarin fruit blemishes and tree-fruit- environment (TFE) profile in relation to various blemishes causal agents
}

\author{
Muhammad Shafique Khalid $^{1 *}$, Samina Khalid ${ }^{1}$, Amjad Farooq ${ }^{1}$, \\ Muhammad Shafique ${ }^{2}$, Atyab Amjad ${ }^{3}$, Muhammad Fakhar Ud Din \\ $\mathrm{Razi}^{2}$, Javaria Sherani ${ }^{4}$ and Irfan $\mathrm{Ali}^{5}$ \\ 1. Department of Environmental Sciences, COMSATS University Islamabad, Vehari Campus, (61100)-Pakistan \\ 2. University of Agriculture, Faisalabad, Sub-Campus Burewala, Vehari-Pakistan \\ 3. Directorate of Floriculture (T\&R), Department of Agriculture, Punjab, Lahore-Pakistan \\ 4. Department of Horticulture, Ghazi University Dera Ghazi Khan-Pakistan \\ 5. Department of Horticulture, Arid Agriculture University, Rawalpindi-Pakistan \\ *Corresponding author's email: shafique.khalid@cuivehari.edu.pk \\ Citation \\ Muhammad Shafique Khalid, Samina Khalid, Amjad Farooq, Muhammad Shafique, Atyab Amjad, Muhammad \\ Fakhar Ud Din Razi, Javaria Sherani and Irfan Ali. Characterization of Kinnow Mandarin fruit blemishes and tree- \\ fruit-environment (TFE) profile in relation to various blemishes causal agents. Pure and Applied Biology. Vol. 10, \\ Issue 4, pp1206-1216. http://dx.doi.org/10.19045/bspab.2021.100127
}

Received: 02/11/2020

Revised: $22 / 01 / 2021$

Accepted: 28/01/2021

Online First: 08/02/2021

\section{Abstract}

Kinnow mandarin (Citrus nobilis Lour $\times$ Citrus deliciosa Tenora) fruit skin blemishes have become the key concern for growers and exporters. The objective of this study was to characterize various fruit skin blemishes, and to develop profile of the dynamics of blemishes in relation to the fruit growth, environmental conditions and various blemishes causal agents. Blemish characterization was done on the basis of visual symptoms, while its development was studied at various phenological stages of the fruit growth and development in relation to insect, pests and disease attack. Blemishes caused by red scales, thrips, mites, citrus canker and anthracnose were characterized among biotic causal agents while wind blemishes were characterized among abiotic causal agents. April and May were found critical months in which, maximum insect pest activity was observed with highest blemish development (36\% and 31\%) respectively. Overall, wind related blemishes $(41.66 \%)$ were found maximum in the orchard followed by mites $(19.89 \%)$. Monthly increment in fruit diameter was maximum $(26.98 \mathrm{~mm})$ during month of June. A total of 3724.08 degree days were estimated for Kinnow mandarin from fruit set to maturity (optimum fruit quality). The study would help the researchers, growers and exporters to identify and develop understanding for better management of Kinnow fruit skin blemishes.

Keywords: Blemishes; Characterization; Environment; Kinnow mandarin

Introduction

Pakistan currently ranks ninth among the mandarin producing countries of the world
[1]. Approximately about $80 \%$ of Pakistan's citrus production comprises of mandarins; predominantly "Kinnow" and according to an 
estimate approximately $95 \%$ of the world "Kinnow" is being produced in Pakistan [2]. "Kinnow" mandarin has got tremendous export potential for fresh consumption. Presently about 250,000 tons of "Kinnow" fruit are being exported mainly to Russia, Middle East and South East Asia [3]. "Kinnow" mandarin cultivation has got significant boost in the country due to its high yielding character. It is appreciated by the consumers both in domestic and international markets due to easy peel, natural deep orange color, good blend of sugars and acids, high juice contents and excellent flavour. Therefore, Kinnow of Pakistan is very popular in different markets worldwide. However, in spite of having good characters, our Kinnow mandarin has lower average price, mainly due to the presence of blemishes on its skin. Pakistan is fetching a prices of $\$ 222 /$ ton for Kinnow mandarin in the international markets as compared to other mandarin exporting countries e.g. Morocco; \$707/ton, Spain; \$1200/ton and China; \$504/ton [4]. Now a day, skin blemishes have become a major concern for the growers and exporters as fruit quality is downgraded, with result of high farm gate rejection and lower international market prices. External presentation of fruit is an important feature to catch consumer choice in the market [5] and attractive, blemish free fruit are desired by the consumer [6]. Morphologically, the blemishes are collapsed hypodermis tissues related to shrunken or destroyed oil glands [7]. Various abiotic (wind, splitting, nutritional imbalance, sun burn) and biotic (insects, diseases and certain microorganisms) factors have been reported to cause blemishes in citrus $[8,9]$.

Previously, information was lacking about blemishes identification and their development in relation to different phenological stages in Kinnow mandarin, since no study was reported in Pakistan on this aspect. So the objective of this study was to characterize various types of skin blemishes of Kinnow mandarin and to develop profile of the dynamics of fruit blemishes in relation to the fruit growth and development and various blemishes causal agents. Also for better estimation of harvesting time, heat units (degree days; DD) were calculated for Kinnow mandarin.

\section{Materials and Methods}

In first stage, nature and characterization of fruit blemishes was assessed based on symptoms [10-12]. In order to have a comprehensive account of the type of blemishes, fruit samples were collected from orchards as well as processing units from district Sargodha. Fruit were photographed and symptoms were noted and differentiated. In second stage, fruit blemishes development was studied in relation to tree phenological stages and environmental conditions. This study was conducted in a commercial orchard in district Sargodha $\left(32^{\circ} 05^{\prime} \mathrm{N} \quad 72^{\circ} 40^{\prime} \mathrm{E}\right)$, which is a major "Kinnow" growing area. All the plant growth and developmental stages were observed during complete growing season. For this purpose, ten healthy trees were selected randomly in the orchard, considering each tree as a replicate. Data regarding different aspects like fruit growth and development, incidence of blemishes on the fruit, time of insect pest attack and disease incidence were recorded from individual tree. Moreover, data regarding the temperature and humidity of the selected orchard was also recorded to relate the environmental effects on fruit growth and development and ultimately on the development of the blemishes. The experiment followed Randomized Complete Block Design (RCBD).

Temperature and humidity measurement A digital data logger (Tiny tag; TGP-4500, Gemini data loggers, (UK) Ltd.) was installed over a Kinnow tree in the experimented field for the whole growing season of (2009-10) to record the data 
regarding temperature and relative humidity (RH).

\section{Heat unit calculation}

Heat units were calculated by the method described by Hardy and Khurshid [13] using the formula:

Daily Heat units $=[($ maximum temperature + minimum temperature $) \div 2]-$ Base temperature

A temperature of $13{ }^{\circ} \mathrm{C}$ was used as base temperate.

\section{Fruit diameter}

Fruit diameter was recorded on monthly basis from the selected trees with the help of digital vernier caliper. Fruit diameter (mm) was recorded from 100 randomly selected fruit; 10 fruit each from 10 tree and average was computed.

\section{Monitoring of incidence of insect pests and diseases}

Observation of the presence of the insect pests on the selected branches of the selected tress was monitored on the Kinnow trees to relate the development of blemishes with incidence of insect pest and diseases.

\section{Blemish development}

For this purpose, 100 randomly selected fruit; 10 fruit each of 10 trees, were observed for the incidence of blemishes at monthly interval (April to July). Percentage of fruit blemishes in the orchard was calculated by the formula:

Blemish percentage $=($ Number of blemished fruit $\div$ total number of observed fruit $) \times 100$

\section{Nature and extent of blemishes in the orchard}

At harvest fruit were assessed for nature and extent of blemishes. The fruit were categorized according to the nature (Biotic and abiotic factors) and extent of blemishes $\left(<1 \mathrm{~cm}^{2}, 1-5 \%, 6-10 \%, 11-25 \%, 26-50 \%\right.$ and $>50 \%$ blemish area covered on fruit skin [9]. The percentages of fruit were calculated in each category.

\section{Results}

\section{Characterization of Kinnow fruit blemishes}

Various types of blemishes were identified in Kinnow mandarin and their characterization with respect to various causal agents is described below.

\section{Red scales}

The blemishes caused by Red scales were identified by the presence of reddish brown small, rounded, hard scales on the skin of the Kinnow fruit (Annexure 1; Plate 1). Major damage occurs to fruit but twigs and leaves also got affected. The scales damage was observed from June to October.

\section{Thrips}

The blemishes caused by thrips were characterized by silvery ring on the stem end or calyx end of the Kinnow fruit. Sometime this ring also extended longitudinally from calyx end (Annexure 1; Plate 2). The damage mainly occurred to fruit. Thrips also destroyed the newly emerging flower buds, resulting low fruit set.

\section{Mites}

Mites were another major biotic factor which caused damage to the skin of the fruit in Kinnow orchards. These blemishes can be characterized by the brownish to reddish spots or irregular patches on skin of the fruit due to mites feeding. Mites feeding may be severe, infecting whole fruit or damage might be low infecting a portion of the skin (Annexure 1; Plate 3). Major damage occurred to the fruit, hence deteriorating the quality of the fruit.

\section{Citrus canker}

Citrus canker is a bacterial disease, caused by a bacterium Xanthomonas axonopodis pv. Citri. [14] and causes major damage to the 
fruit. The symptoms were characterized by formation of corky, blackish to brownish lesions on the skin of the fruit. These spots downgrade the quality of the fruit and make it non exportable (Annexure 1; Plate 4).

\section{Anthracnose}

Anthracnose is caused by fungus called Colletotrichum gloeosporioides [15]. Anthracnose was characterized by sunken, black lesions or superficial, reddish brown discoloration. (Annexure 1; Plate 5). The major damage occurred to the fruit causing quality and quantitative loss.

\section{Wind blemishes}

Wind blemishes were the most common fruit blemishes found in the Kinnow orchards. The blemishes are characterized by irregular and uneven scratches found on the skin of the Kinnow fruit (Annexure 1; Plate 6).

\section{Stylar end deformity}

The problem is characterized by breakdown of peel from stylar end of the fruit in rounded pattern (Annexure 1; Plate 7).

\section{Branch rubbing of fruit}

Branch rubbing is also common in Kinnow orchards especially if orchard is not pruned regularly. Fruits near to branches may be exposed to rubbing causing severe scratches or may rupture to the skin of the fruit (Annexure 1; Plate 8).

\section{Poor tree/canopy management}

The fruit become trapped in between the branches of the tree. The fruit becomes misshapen/deformed and loses the quality (Annexure 1; Plate 9).

Tree-fruit-environment (TFE) Profile

A Tree-Fruit-Environment (TFE) profile was made to relate the Kinnow fruit skin blemishes development with environmental conditions (Fig. 1). New growth (flushing) was observed during third week of February (at mean temperature $18.04^{\circ} \mathrm{C}$ ) but frequent and major flushing was observed during the month of March (at mean temperature19.74 $\left.{ }^{\circ} \mathrm{C}\right)$. Maximum temperature $\left(42.73{ }^{\circ} \mathrm{C}\right)$ was recorded on $28^{\text {th }}$ June, 2009 season and minimum (4.94 $\left.{ }^{\circ} \mathrm{C}\right)$ temperature was recorded on $20^{\text {th }}$ January, 2009 season. Regarding mean temperatures, mean maximum temperature $\left(38.16^{\circ} \mathrm{C}\right)$ was observed during the month of June, while mean minimum temperature $\left(7.47^{\circ} \mathrm{C}\right)$ was observed in the month of January. Similarly, maximum humidity (100\%) was recorded on $28^{\text {th }}$ March, 2009, however, mean maximum relative humidity $(66.99 \%)$ was recorded during the month of August and mean minimum $(1.14 \%)$ in December. The profile also reflects the time of attack of different insect pest and disease in relation to temperature and humidity during different months. Attack of aphid was observed in February at mean temperature of $18.06^{\circ} \mathrm{C}$. During the month of March, leaf miner and white fly were found along with aphid with monthly mean temperature of $19.73{ }^{\circ} \mathrm{C}$. During the months of April, May and June; severe attack of psylla and mealy bug was observed. The mean temperatures recorded during these months were $26.19^{\circ} \mathrm{C}, 32.68^{\circ} \mathrm{C}$ and $34.09{ }^{\circ} \mathrm{C}$ respectively. Mites appeared during the month of May when mean temperature was $32.68{ }^{\circ} \mathrm{C}$ with $43 \%$ mean $\mathrm{RH}$. Fruit fly was observed in the orchard during August. Colour break in fruit started during first week of October at temperature of $23.72{ }^{\circ} \mathrm{C}$ and $52.17 \%$ of $\mathrm{RH}$. Minor incidence of citrus canker was observed during month of June and stem end breakdown during late harvest in March. March $\left(19.73{ }^{\circ} \mathrm{C} ; 63.47 \% \mathrm{RH}\right)$ was identified as an important month for Kinnow tree due to the occurrence of many critical phenological stages (new flush emergence, flower bud opening, fecundation and fruit set).

Kinnow fruit skin blemish development After fruit set (last week of March) eight weeks were found critical for the development of Kinnow fruit skin blemishes as maximum percentage of blemish development was recorded during this period. Significantly higher blemishes (36\%) 
were recorded within first month after fruit set i.e. April $\left(26.19{ }^{\circ} \mathrm{C} ; 55 \% \mathrm{RH}\right)$ and $31 \%$ blemish development during May $\left(32.68^{\circ} \mathrm{C}\right.$; $43 \% \mathrm{RH})$ followed by $19 \%$ during June (34.09 $\left.{ }^{\circ} \mathrm{C} ; 44.71 \% \mathrm{RH}\right)$, July recorded minimum $(5 \%)$ blemish development at $37.08^{\circ} \mathrm{C}$ and $59.75 \%$ RH (Fig. 2).

Fruit growth and development

Gradual increase in fruit diameter was observed after the fruit set to harvesting. Significantly higher monthly increment in fruit diameter was recorded during the month of the June (26.98) mm followed by July (10.18) (Fig. 3). Other months showed more or less similar and steady increase in fruit size.

Heat units/degree days for Kinnow fruit growth and development

New flush emergence was observed from third week of the February which continued up to first week of March. It required 62.71 degree days and the mean difference in day and night temperatures in February and March was $6.90{ }^{\circ} \mathrm{C}$ and $7.33^{\circ} \mathrm{C}$, respectively. Flower emergence was observed from second week of March while fruit setting was observed till end of March and 162.55 degree days were recorded during this stage (Table 1). Colour break was observed on $1^{\text {st }}$ October and by that time 3280.2 degree days were accumulated from fruit set. $\left(1^{\text {st }}\right.$ April- $1^{\text {st }}$ October). A total of, approximate 3724.08 degree days were estimated for Kinnow mandarin from fruit set to maturity. Total soluble solids (TSS) at peak maturity (optimum fruit quality) were recorded as 10.6 ${ }^{\circ}$ Brix (Fig. 4).

Nature and extent of blemishes in the orchard

Regarding nature of blemishes, wind blemished fruit (41.82\%) were found significantly higher in the orchard followed by mites which produced $19.89 \%$ of blemished fruit (Fig. 5). Blemishes caused by wind, mites and physical were found in orchard under study, while no fruit were found blemished with thrips and citrus canker. Regarding extent of blemishes, significantly higher percentage of fruit $(35 \%)$ were found in $1-5 \%$ blemish area category, followed by $<1 \mathrm{~cm}^{2}$ blemish category with $30 \%$ fruit (Fig. 6).

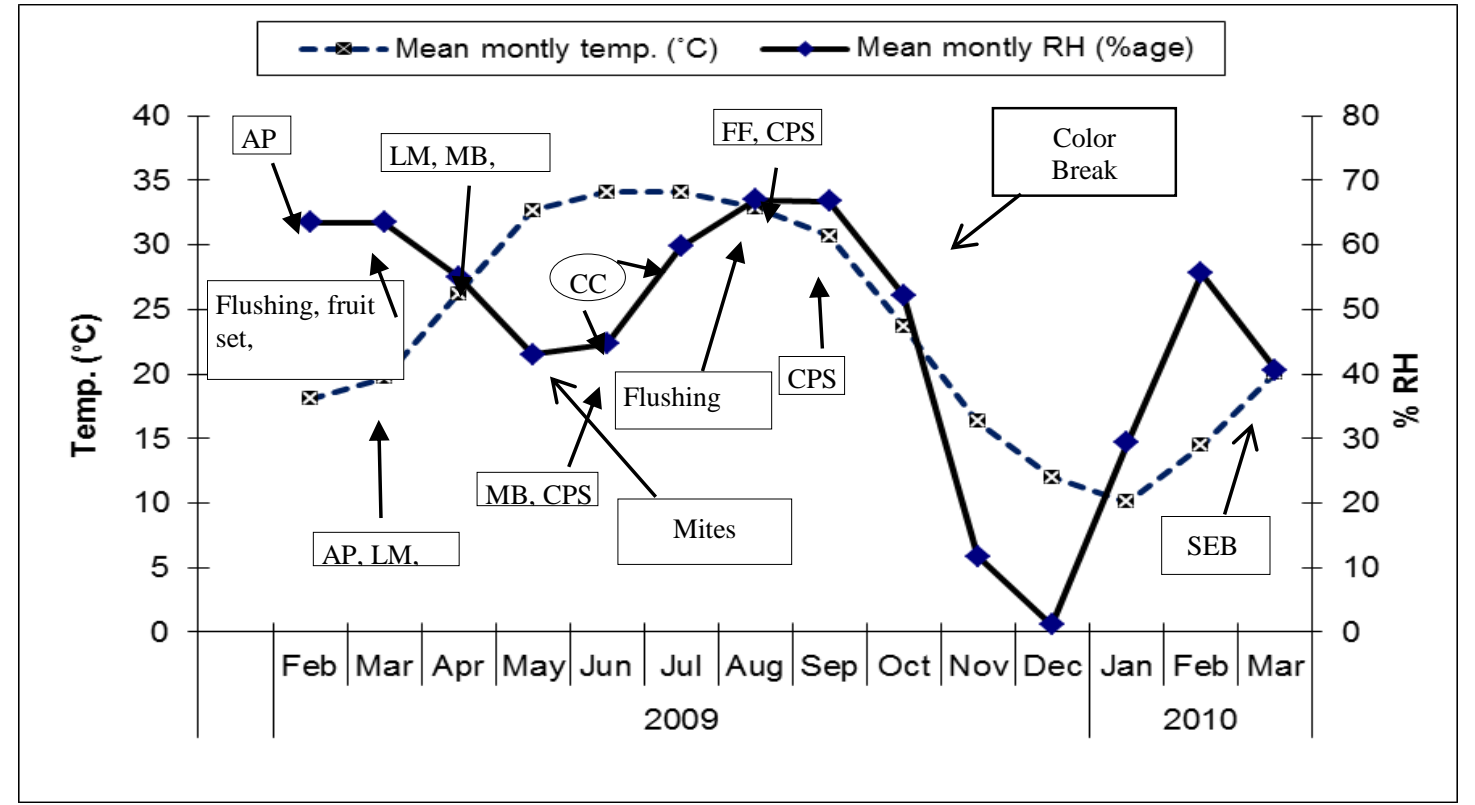

$(\mathrm{AP}=$ Aphid, $\mathrm{LM}=$ Leaf Miner, $\mathrm{MB}=$ Mealy Bug, $\mathrm{CPS}=$ Citrus Psylla, $\mathrm{FF}=$ Fruit Fly, WF= White Fly, Mt= Mites, $\mathrm{CC}=$ Citrus canker, $\mathrm{SEB}=$ Stem end breakdown)

Figure 1. A Tree-Fruit-Environment (TFE) Profile showing the timeline of phenological stages of Kinnow tree, fruit growth and developmental stages, disease and pest attack 
Khalid et al.

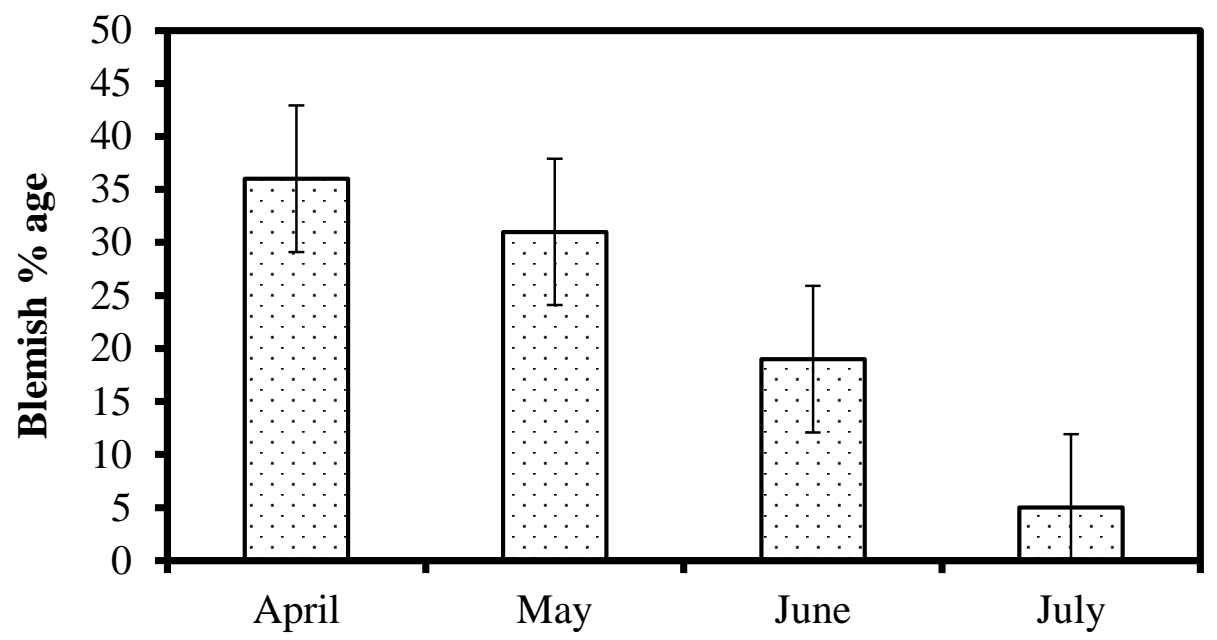

Figure 2. Development of Kinnow skin fruit blemishes after fruit set

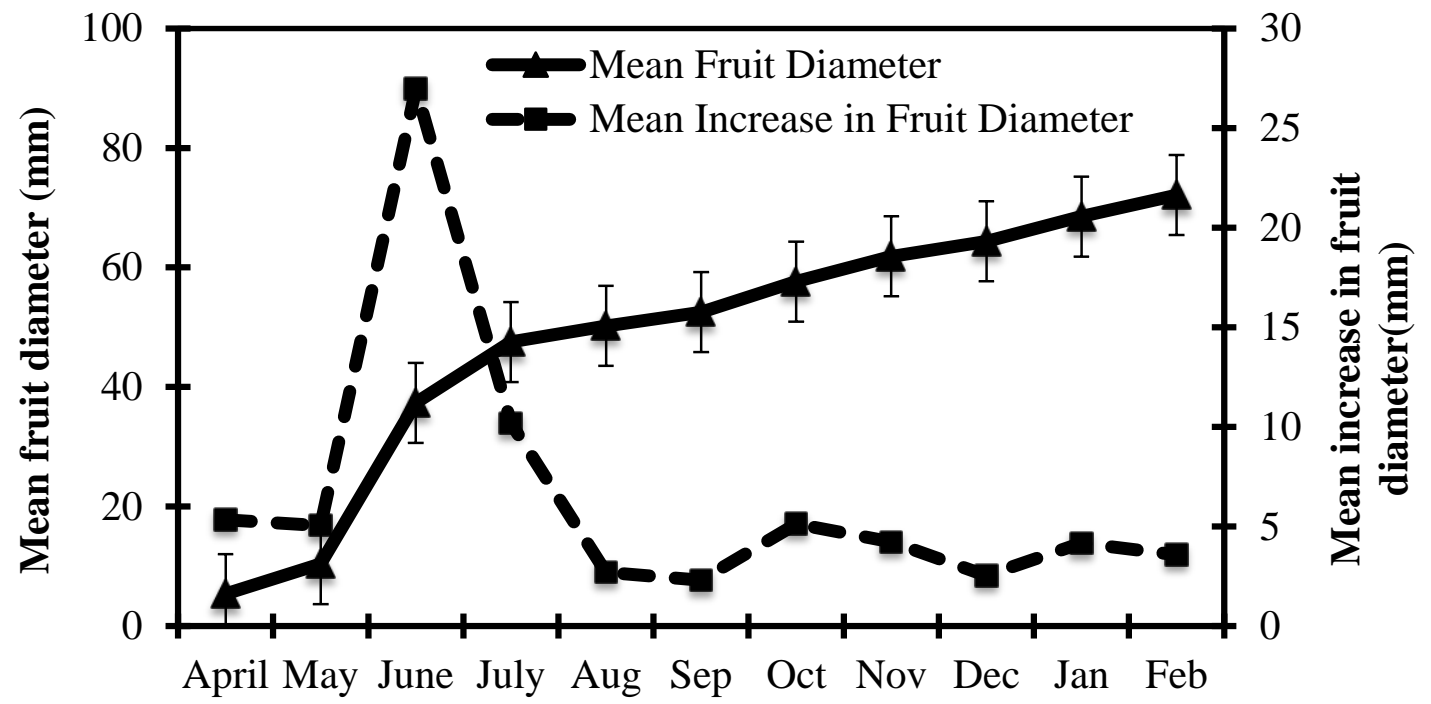

Figure 3. Mean fruit diameter and mean increase in fruit diameter during the season

Table 1. Heat Units requirements (Degree Days) for different Growth/developmental stages in Kinnow mandarin

\begin{tabular}{|c|c|c|c|}
\hline $\begin{array}{c}\text { Growth/Development } \\
\text { Stage }\end{array}$ & Time (approximate) & Daily Heat Units (DD) & $\begin{array}{c}\text { Cumulative } \\
\text { DHU (DD) }\end{array}$ \\
\hline Flushing & 20 Feb to 7 March & 62.71 & 225.26 \\
(FL to FS) \\
\hline Flowering to Fruit set & 8 March to 31 March & 162.55 & 3724.08 \\
& 1 April to 1 October & 3280.2 & (FS to PM) \\
\hline Fruit set to color break & 1 October to 15 Jan & 443.88 & \multirow{3}{3}{ Color break to harvesting } \\
\cline { 1 - 2 } $\begin{array}{c}\text { Fruit set to commercial } \\
\text { maturity }\end{array}$ & 1 April to 1 Dec & -- & $\mathbf{3 9 4 9 . 3 3}$ \\
\hline Flushing to harvesting & 20 Feb to 15 Jan & -- & \\
\hline
\end{tabular}

$\mathrm{FL}=$ Flushing; FS $=$ Fruit set; HRV= Harvesting; $\mathrm{DD}=$ Degree days; DHU = Daily heat unit; PM= Peak maturity (optimum fruit quality) 


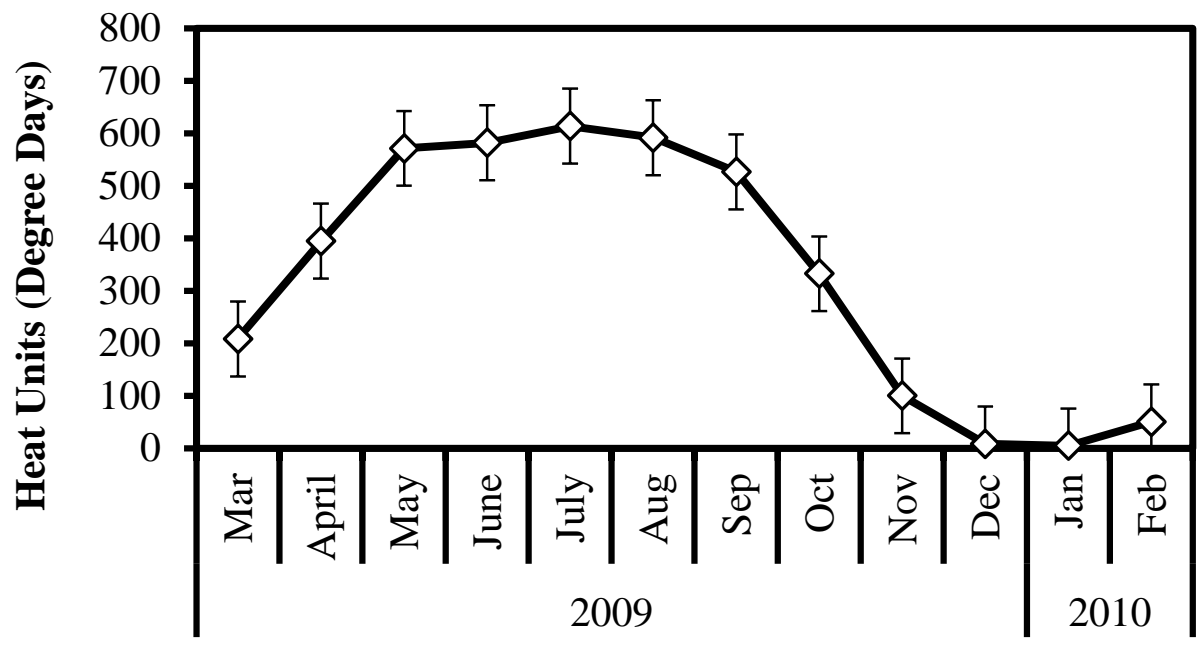

Figure 4. Monthly accumulated heat units during the Kinnow growing season

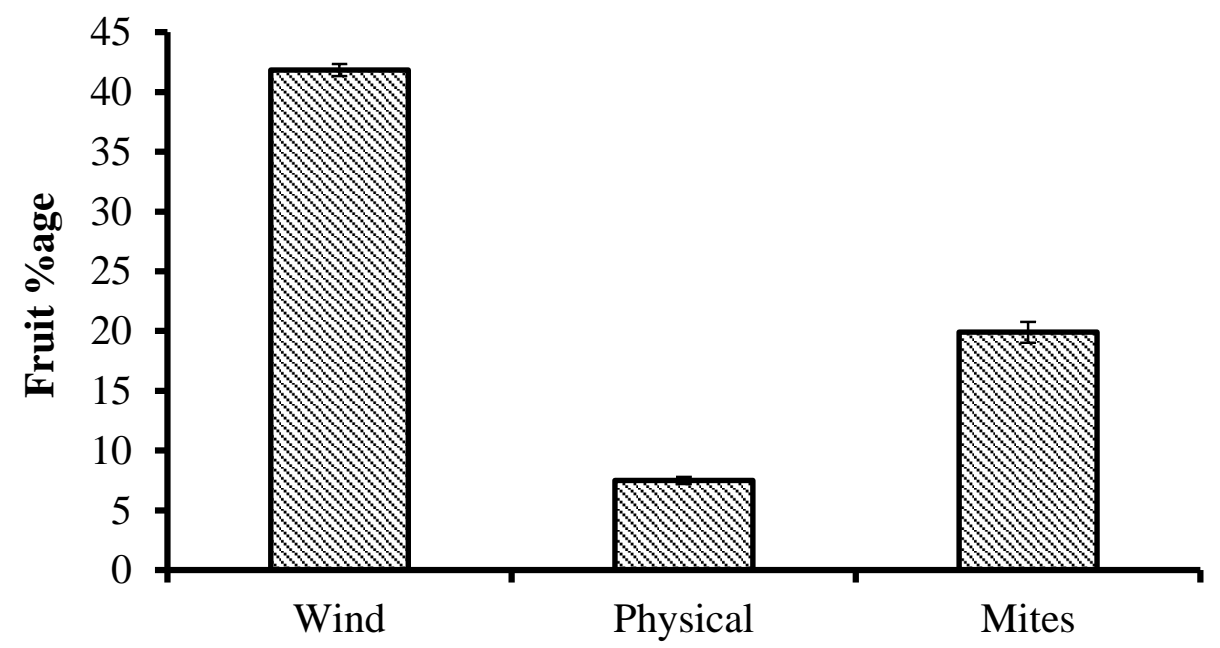

Figure 5. Nature of blemishes in the orchard

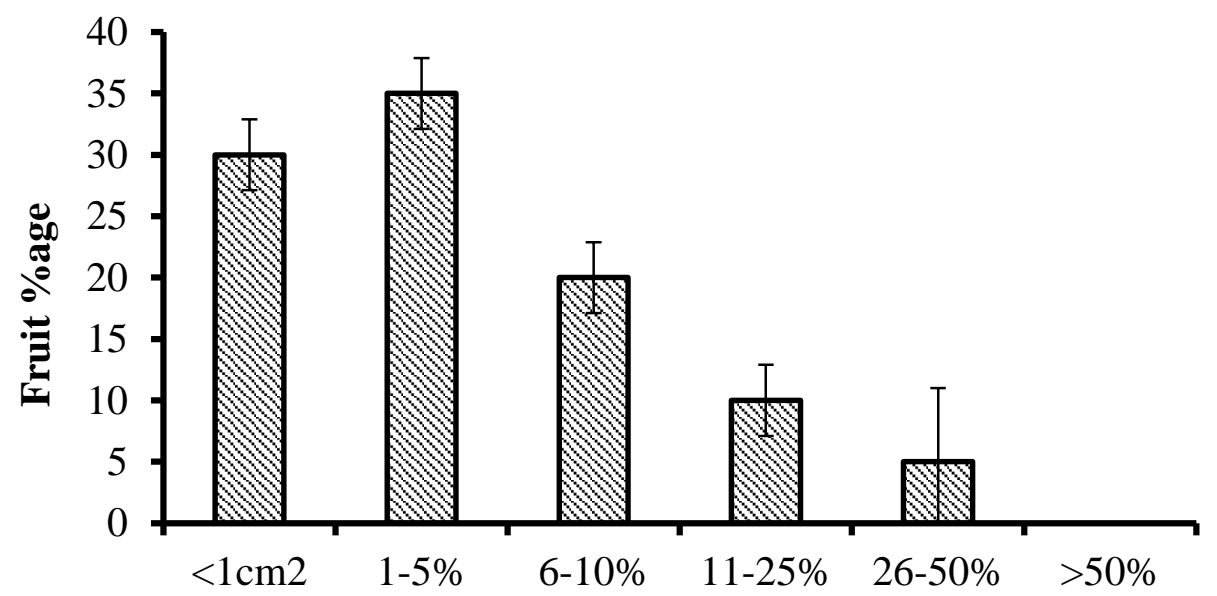

Figure 6. Extent of fruit blemishes in the orchard (at harvest) 


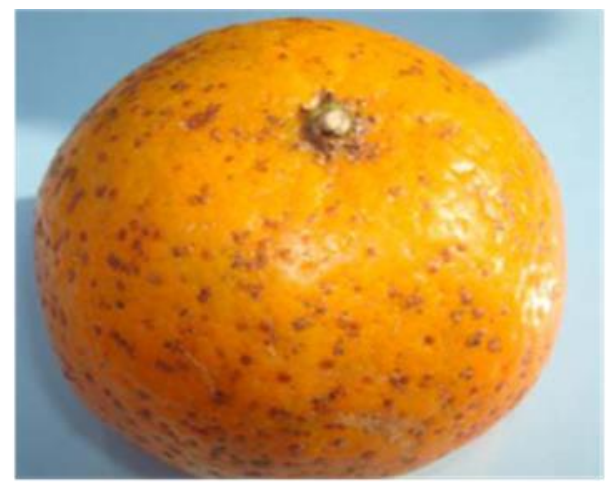

Plate 1: Blemishes caused by Red Scales

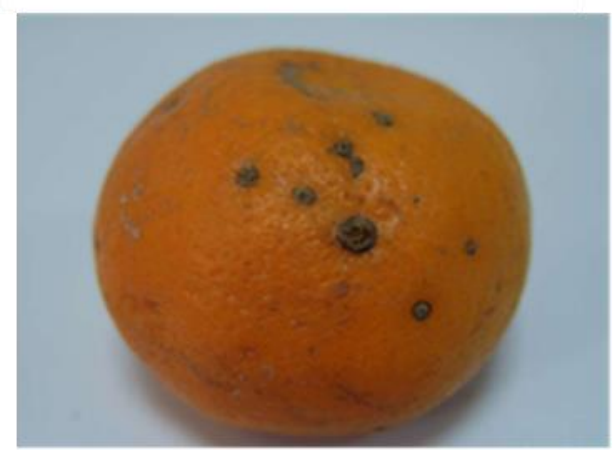

Plate 4: Blemishes caused by Citrus Canker

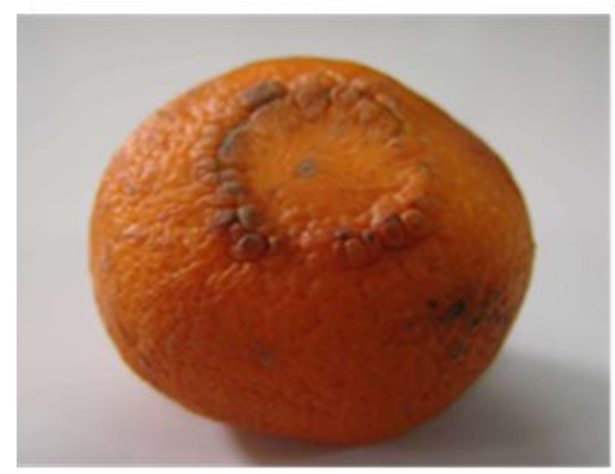

Plate 7: Styler end Deformity

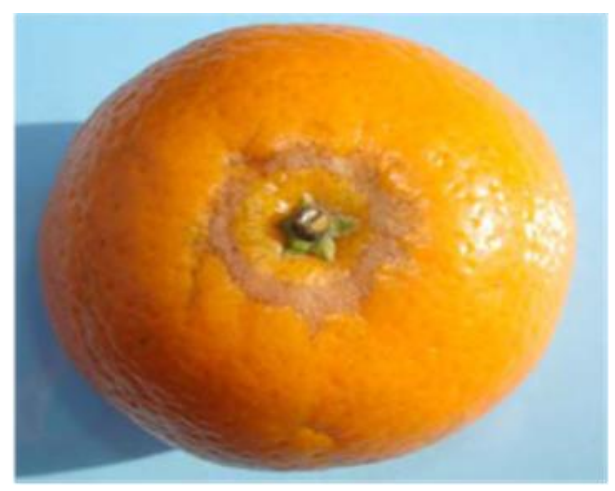

Plate 2: Blemishes caused by Thrips

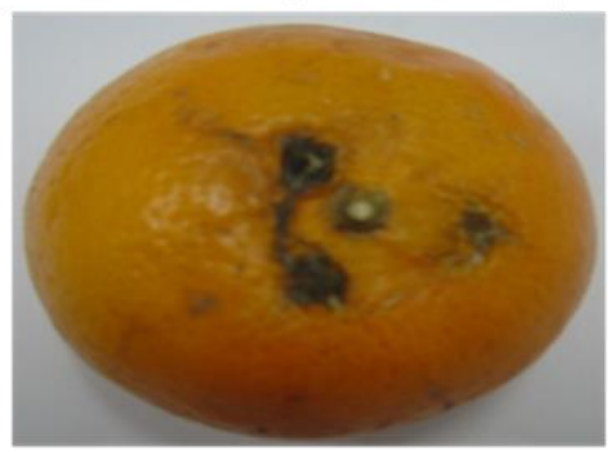

Plate 5: Blemishes caused by Anthracnose

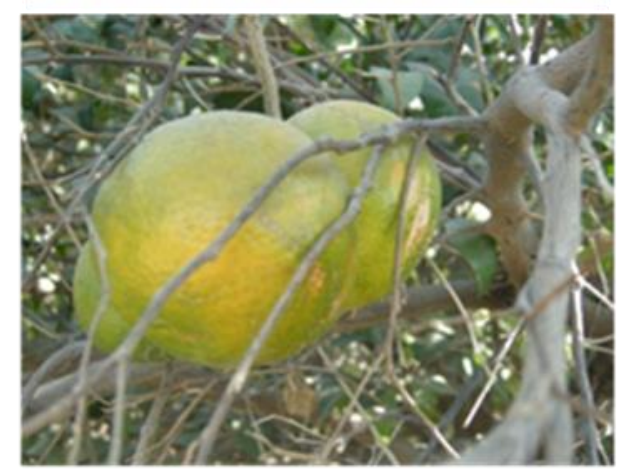

Plate 8: Blemishes caused by Branch rubbing

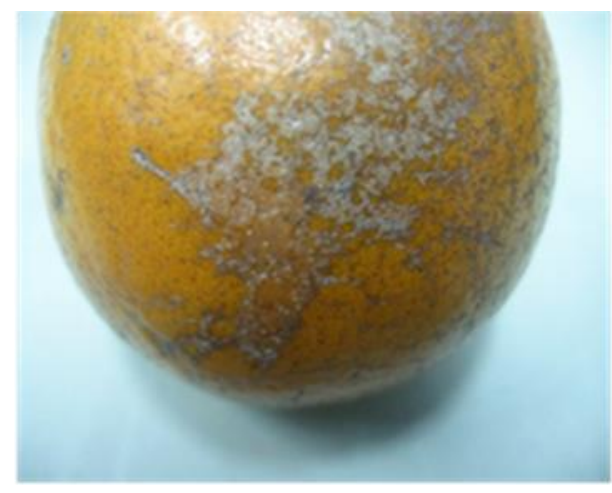

Plate 3: Blemishes caused by Mites

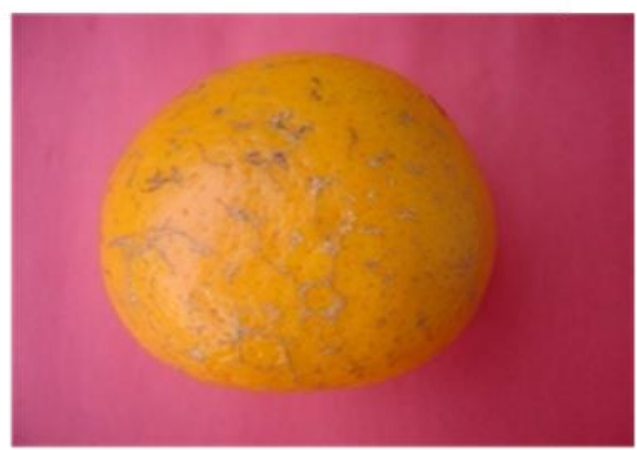

Plate 6: Blemishes caused by Wind

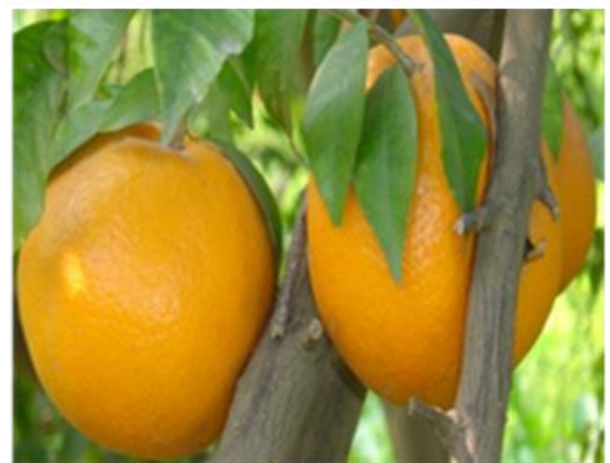

Plate 9: Misshapen fruit due to poor canopy management Annexure 1. Various types of Blemishes in Kinnow Mandarin

\section{Discussion}

Fruit were characterized according to visual symptoms and it was found that symptoms of blemishes due to red scales, thrips, mites, citrus canker, anthracnose and wind, on Kinnow mandarin were similar to, as described previously by Cardwell et al. [10], Schubert and Sun [11], Beattie and Gellatley
[12]. A Tree-Fruit-Environment (TFE) profile was developed which pin points the critical times of growth and development of Kinnow plant and fruit. In citrus, differentiation of flower and vegetative buds occur just at bud sprouting close to the end of the cold season [16, 17]. Similar type observations were recorded in our studies, as 
bud differentiation, flowering opening, fertilization and fruit set was observed at the end of winter season. The profile also highlights the times of insect pest and disease attack on Kinnow mandarin during whole season. Controlling insect pest and diseases at proper time which are responsible for skin blemishes in Kinnow mandarin is key to the management of blemishes. Plant protection and nutrition management interventions can be more effective if in line with critical times (time of insect pests and disease attack, plant and fruit development stages etc.) as described in the TFE profile.

Growth and development of plants are directly dependent on the quantity of heat they received [13]. Same is true for the insect pest, attack on plants. The flushing of Kinnow mandarin under agro-ecological conditions Sargodha normally starts in third week of February and optimum fruit quality is achieved in mid-January [18]; although commercial harvest and export starts from $1^{\text {st }}$ December. The attack of different insect pests started right from emergence of new flushes. The attack of aphid, leaf miner, white fly, psylla, mealy bug and mites were observed at different temperature regimes. March and April were pronounced with the biotic factors as aphid and leaf minor were observed during March, mealy bug and citrus psylla along with leaf minor during April and mites were observed during May. Stem end breakdown (SEB) was noticed during March (late harvest of fruit) and categorized under abiotic factor of blemish (Fig. 1). This supports the statement that, certain insects and mites developmental rates vary with temperature, which has a direct effect on the metabolic processes [19]. March is considered as critical month for Kinnow mandarin as flower opening, fertilization and fruit set occurs in this month. The fruit skin blemishes development starts right after fruit set. As per findings of the study, $36 \%$ of the fruit blemishes were developed during the month of April and $31 \%$ during the month of May. Higher percentage of wind blemished fruit $(41.66 \%)$ were found in our studies and these results supports the earlier findings which also suggested that wind scarring is a major blemish problem in citrus groves [20]. Similarly $19 \%$ of fruit skin blemishes were developed during the month of June and 5\% during July. Maximum fruit skin blemish development was observed during the months of April and May. Maximum insect pest activity was also observed during this period of blemish development. Citrus psylla, mealy bug, leaf miner and mites were observed in this period of blemish development. The development of blemishes decreased gradually with time. Decreasing trend of blemishes was observed with relation to increase in temperature and monthly heat sums. So, it was observed that maximum fruit skin blemishes were developed within 8 weeks of fruit set. These findings supports the earlier results of Freeman [20] and Brodrick [21] which state that citrus fruitlets are susceptible to abrasive injury in an almost exclusive period of within 12 weeks from petal fall. Proper plant protection should be observed during this period.

The response of fruit at different developmental stages in relation to temperature varies considerably [22]. Variation in fruit growth and development in relation to temperature was also found in our study. Maximum mean increment in fruit diameter was recorded during the month of June which indicates that fruit growth and development is directly linked to temperature and heat sum. Mean average temperature of $34.09{ }^{\circ} \mathrm{C}$ and heat sum of 582.03 degree days were recorded during this month. This results are supported by the previous findings where growth and development of plants are directly related to the quantity of heat received and fruit development was very fast under high temperature prevailing $[13,23]$. 
Temperature also affects rind color development of the citrus. The decline in air and soil temperatures during autumn marks the beginning of colour changes in the subtropics [24]. Colour break was observed in our study during first week of October, when average temperature was $23.72{ }^{\circ} \mathrm{C}$, which was substantially lower than September $\left(30.70^{\circ} \mathrm{C}\right)$.

\section{Conclusion}

Blemishes caused by Red scales, thrips, mites, citrus canker and anthracnose were characterize among biotic factors whereas wind blemish was characterize under abiotic factor. April and May were the critical months for blemishes development. These months also recorded the highest insect pest's activity on Kinnow tree. Maximum fruit growth and development occurred during June and July when maximum heat units were available. Overall wind blemishes were found higher on fruit followed by mites with $41.82 \%$ and $19.89 \%$ of fruit respectively. Kinnow requires 3718.11 and 3724.08 accumulated heat units/ degree days from fruit set to commercial maturity $\left(1^{\text {st }}\right.$ December) and optimum fruit quality (midJanuary) respectively. This information can be helpful for the growers/stakeholders for better understanding and management of fruit blemishes development and harvest quality.

\section{Authors' contributions}

Conceived the idea and conducted a research: MS Khalid, Helped in completing analysis, data analysis, and manuscript completion: $S$ Khalid, A Farooq, M Shafique, A Amjad, MF UD Razi, J Sherani \& I Ali.

\section{Acknowledgments}

Author gratefully acknowledges the financial support of "Higher Education Commission (HEC)," Islamabad, for the completion of current research under the Indigenous $\mathrm{PhD}$ 5000 Batch VI Fellowship Scheme.

\section{References}

1. FAO Stat (2009). Food and Agriculture Organization.
2. Khurshid T (2007). Citrus project in Pakistan. In: (Ed.). Agriculture Today.

3. Anonymous (2010). Pakistan PHDEC Sets Export Target for Kinnow. http://www.atcitrus.com/english/noticia. asp? seccion $=$ principales \&id $=765$

4. FAO (2008). Food and Agriculture Organization.

5. Dandekar AM (2004). Improving Peel Quality of California Citrus Fruit. Citrus Research Board, Annual Report, Horticultural Sciences, University of Florida, Gainesville.

6. Chaparro JX (2004). Breeding a Red Fleshed Mandarine (Candidate Gene Analysis). Citrus Research Board, Annual Report, Horticultural Sciences, University of Florida, Gainesville.

7. Safran H (1975). Physiological disorders, environmental and chemical injuries of Citrus, In: Blemishes and deficiencies of Citrus in Israel. Sifriat hapoalim TelAviv. pp. 110-115.

8. Albrigo LG (1978). Occurrence and identification of preharvest fruit blemishes in Florida citrus orchards. Proc Fla State Hort Soc 91: 78-81.

9. Ahmed M (2005). Nature and extent of fruit blemishes in Kinnow mandarin. MSc thesis. Deptt. of Horticulture, Univ Agri, Faisalabad

10. Cardwell, GEE, Connel NVO, Kallsen CE \& Morse JG (2003). Photographic guide to citrus fruit scarring. ANR publication 8090. Division of Agriculture and Natural Resources; University of California.

11. Schubert TS \& Sun X (2003). Bacterial citrus canker. Plant Pathology Circular No. 377. Fl. Deptt. of Agriculture \& Cons. Svcs, Division of Plant Industry.

12. Beattie GAC \& Gellatley JG (2003). Mite pests of citrus. AG Facts, NSW Agriculture Division of Agricultural Services. 
13. Hardy S \& Khurshid (2007). Calculating heat units for citrus. Primefacts 749. NSW Department of Primary Industries. ISSN 1832-6668.

14. Kumar S, Mackie A \& Burges N (2004). Citrus canker Xanthomonas axonopodis pv citri. Farmnote. Deptt. of Agriculture, Government of Western Australia.

15. Brown GE (1994). Anthracnose, causal organism and disease cycle. PP136, IFAS Extension, University of Florida.

16. Guardiola JL, Monerri C \& Agusti MM (1982). The inhibitory effect of gibberellic acid on flowering in citrus. Physiol Plant 55: 136-142.

17. Lord EM \& Eckard KJ (1985). Shoot development in Citrus sinensis L. (Washington Navel orange). I. Floral and inflorescence ontogeny. Bot Gaz 146: 320-326.

18. Javed MA (2007). Developing Kinnow quality profile in relation to different harvest dates and geographical locations. M.Sc. thesis, Deptt. of Horticulture, Univ. Agri., Faisalabad.
19. Logan JA, Wolkind DJ, Hoyt SC \& Tanigoshi LK (1976). An analytical model for description of temperature dependent rate phenomenon in arthropods. Envir Ento 5: 1133-1140.

20. Freeman B (1976). Rind blemishes of citrus. I. Initiation and development. Sci Hort 4: 317-327.

21. Brodrick HT (1970). Investigating into blemishes on citrus fruits. S Afr Citrus $J$ 441: 7-13.

22. Newman JE, Copper WC, Reuther W, Cahoon GA \& Peynado A (1967). Orange fruit maturity and net heat accumulation. In: Shaw RH, Editor. Ground Level Climatology. Am Assoc Adv Sci Publ 86: 27-47.

23. Roy SP \& Goldschmidt EE (1996). Biology of citrus. Cambridge University press, pp. 98-101.

24. Young LB \& Erickson LC (1961). Influence of temperature on color change in Valencia oranges. Proc Am Soc Hort Sci 78: 197-200. 